\title{
MAPK uncouples cell cycle progression from cell spreading and cytoskeletal organization in cycling cells
}

\author{
Coert Margadant $\cdot$ Lobke Cremers • \\ Arnoud Sonnenberg • Johannes Boonstra
}

Received: 30 November 2011 /Revised: 19 July 2012/ Accepted: 23 July 2012/Published online: 25 August 2012

(C) The Author(s) 2012. This article is published with open access at Springerlink.com

\begin{abstract}
Integrin-mediated cytoskeletal tension supports growth-factor-induced proliferation, and disruption of the actin cytoskeleton in growth factor-stimulated cells prevents the re-expression of cyclin $\mathrm{D}$ and cell cycle re-entry from quiescence. In contrast to cells that enter the cell cycle from G0, cycling cells continuously express cyclin D, and are subject to major cell shape changes during the cell cycle. Here, we investigated the cell cycle requirements for cytoskeletal tension and cell spreading in cycling mammalian cells that enter G1-phase from mitosis. Disruption of the actin cytoskeleton at progressive time-points in G1phase induced cell rounding, FA disassembly, and attenuated both integrin signaling and growth factor-induced $\mathrm{p} 44$ / p42 mitogen-activated protein kinase activation. Although cyclin D expression was reduced, the expression of cyclin A and entry into S-phase were not affected. Moreover, expression of cyclin B1, progression through G2- and M-phase, and commitment to a new cell cycle occurred normally. In contrast, cell cycle progression was strongly prevented by inhibition of MAPK activity in G1-phase, whereas cell spreading, cytoskeletal organization, and integrin signaling were not impaired. MAPK inhibition also prevented cytoskeleton-independent cell cycle progression.
\end{abstract}

Electronic supplementary material The online version of this article (doi:10.1007/s00018-012-1130-2) contains supplementary material, which is available to authorized users.

C. Margadant $\cdot$ L. Cremers $\cdot$ J. Boonstra

Department of Cell Biology, Faculty of Sciences,

University of Utrecht, Padualaan 8, 3584 CH Utrecht,

The Netherlands

C. Margadant $(\bowtie) \cdot$ A. Sonnenberg

Department of Cell Biology, The Netherlands Cancer Institute,

Plesmanlaan 121, 1066 CX Amsterdam, The Netherlands

e-mail: c.margadant@nki.nl
Thus, these results uncouple the requirements for cell spreading and cytoskeletal organization from MAPK signaling, and show that cycling mammalian cells can proliferate independently of actin stress fibers, focal adhesions, or cell spreading, as long as a threshold level of MAPK activity is sustained.

Keywords Actin cytoskeleton - Cell cycle progression . Cell spreading · Cyclin · Focal adhesion · G1-phase . Integrin $\cdot$ Mitogen-activated protein kinase $\cdot$ Mitosis

\author{
Abbreviations \\ CCD Cytochalasin D \\ ECM Extracellular matrix \\ F-actin Filamentous actin \\ FA Focal adhesion \\ FAK Focal adhesion kinase \\ FN Fibronectin \\ LB Latrunculin B \\ MAPK Mitogen-activated protein kinase
}

\section{Introduction}

Cell cycle progression in normal mammalian cells requires both growth factor stimulation and cell adhesion to the extracellular matrix $(\mathrm{ECM})$ mediated by transmembrane heterodimeric $\alpha \beta$ receptors called integrins [1, 2]. Engagement of virtually all integrins leads to the assembly of large macromolecular complexes called focal adhesions (FAs), at least in cells in culture, where they connect to actin stress fibers. In this way, integrins generate intracellular tension, mediate cell spreading over the substrate, and initiate several signaling pathways $[3,4]$. Disruption of stress fibers with 
pharmacological agents prevents integrin-mediated cell spreading, and inhibits growth-factor-induced re-entry into G1-phase from quiescence [5-14]. Cell cycle arrest upon cytoskeletal disruption is characterized by a failure to downregulate the cell cycle inhibitor $\mathrm{p} 27^{\mathrm{KIP} 1}$, to induce sustained p44/p42 mitogen-activated protein kinase (MAPK) phosphorylation and activation, and to induce expression of D-type cyclins, which together with cdk $4 / 6$ are essential factors for promoting G1/S-phase progression [12-15]. The same is observed upon loss of adhesion, or restriction of cell spreading on micro-patterned surfaces [16-18].

Induction of cyclin D expression is crucial for growth factor-stimulated re-entry into G1-phase from quiescence, and is the main step that is sensitive to cytoskeletal tension [5, 6, 19-22]. Overexpression of cyclin D1 can rescue proliferation in non-adherent cells, and is often associated with the anchorage-independent growth of tumor cells [2326]. It thus seems that the requirement of cell spreading for proliferation is not absolute, and that cell cycle progression and cell spreading can be disconnected as long as cyclin D1 is expressed. Indeed, normal G0- to S-phase progression in fibroblasts depends on integrin-sustained Rho activation, stress fiber formation and cell spreading, which leads to mid-G1-phase induction of cyclin D expression [27, 28]. However, upon inhibition of Rho signaling, a Rac/Cdc42driven pathway induces early expression of cyclin D and shortening of G1 phase, and allows for cell cycle progression in the absence of stress fibers or cell spreading [28]. Hence, depending on the circumstances, cells may switch between a tension-dependent and -independent mode of proliferation, provided that there is a signal to induce cyclin D.

Consistent with such a model, we have previously shown that in cycling cells (i.e., as opposed to cells entering G1phase from quiescence), which express cyclin $\mathrm{D}$ and contain low levels of cell cycle inhibitors, prevention of postmitotic stress fiber assembly and concomitant cell spreading does not inhibit progression through G1-phase [29]. We hypothesize that after cytokinesis, cells can commit to a new cycle either in a high-tensional state with extensive stress fibers and FAs, or rounded without extensive stress fibers and FAs, depending on the environmental requirements and/or restraints. Possibly, cell spreading elicits an irreversible cell-cycle program so that artificial cell rounding will inhibit cell cycle progression, which would explain why quiescent, spread cells do not enter the cell cycle upon cytoskeletal disruption. In addition, M-to-Sphase progression may only require cytoskeletal integrity and cell spreading during a discrete time-window, as has been observed for capillary endothelial cells that re-enter G1-phase from quiescence [30].

In the present study, we explored the requirements for cell spreading, stress fibers, FAs, and MAPK signaling in cell cycle progression in cycling cells, as well as the crosstalk between MAPK, cell spreading and the cytoskeleton. We have focused on cell cycle progression supported by fibronectin (FN), as most studies concerning integrinmediated cytoskeletal tension and proliferation center on FN-binding integrins, most importantly integrin $\alpha 5 \beta 1$ [27, $28,31,32]$. To obtain synchronized cycling cells, we have collected cells from asynchronously growing cultures of $\mathrm{N} 2 \mathrm{~A}$ and $\mathrm{CHO}$ cells by mitotic shake-off, which yields high numbers of cells in cytokinesis without the use of metaphase-blocking agents such as nocodazole, and we have previously extensively characterized cell cycle regulation in these cells $[29,33,34]$. Although both cell lines are mitogen- and adhesion-dependent, we also investigated cell cycle progression in non-transformed mouse GE $\beta 1$ cells, as the tensional requirements for cell cycle progression are frequently lost in transformed cells [5].

\section{Materials and methods}

\section{Antibodies and other materials}

CCD, DMSO, FN, UO126, and TRITC-conjugated phalloidin were from Sigma (Steinheim, Germany). BrdU was from Invitrogen, DAPI was from Boehringer-Mannheim, and LB was from Calbiochem (San Diego, CA). CCD and LB were prepared as $1 \mathrm{mg} / \mathrm{ml}$ stock solutions in DMSO, and further diluted in culture medium to the indicated concentrations. Antibodies used in this study were directed against BrdU (Bu20a from DAKO, Carpinteria, CA), Cyclin A (Oncogene), Cyclin B1 (Santa Cruz), Cyclin D1/ D2 (Upstate Biology), FAK (Transduction Laboratories), p42 MAPK (Upstate Biology), paxillin (Transduction Laboratories), P(p44/p42) MAPK (Cell Signalling Technology), P(Y) (4G10; a kind gift of Dr. K. Wilhelmsen), P(Y397)FAK (Invitrogen), P(Y925)FAK (Biosource), $\mathrm{P}(\mathrm{Y} 31)$ paxillin and $\mathrm{P}(\mathrm{Y} 118)$ paxillin (Biosource), securin (Abcam), and vinculin (Sigma). FITC-, TRITC-, CY5-, and Hrp-conjugated secondary antibodies were purchased from Jackson ImmunoResearch Laboratories.

\section{Cell culture and synchronization}

N2A (Neuro2A) cells were derived from a spontaneous murine neuroblastoma, $\mathrm{CHO}$ cells were isolated from the ovary of an adult Chinese hamster, and GE $\beta 1$ cells were generated by stable expression of the integrin $\beta 1$-subunit into epithelial GE11 cells derived from the $\beta 1$-null mouse embryo [35]. All cell lines were maintained in DMEM supplemented with 10\% FCS (Gibco) and penicillin/ streptomycin $(100 \mathrm{U} / \mathrm{ml})$ at $37^{\circ} \mathrm{C}$ and $5 \% \mathrm{CO}_{2}$. Mitotic cells were obtained by shaking asynchronously growing 
cell cultures firmly by hand for $1 \mathrm{~min}$ at $37^{\circ} \mathrm{C}$, and collecting the medium as described previously [36]. After shake-off, mitotic cells were released on coverslips (Menzel, Germany) or in tissue-culture plates (Corning, $\mathrm{NY})$ at a density of $1.5 \times 10^{4}$ cells $/ \mathrm{cm}^{2}$. Coverslips and tissue-culture plates were coated with FCS and FN $(10 \mu \mathrm{g} /$ $\mathrm{ml}$ ) over night at $37^{\circ} \mathrm{C}$.

\section{Western blotting}

Cells were washed once with ice-cold PBS and subsequently lysed on ice in RIPA buffer $(20 \mathrm{mM}$ Tris/ $\mathrm{HCl}(\mathrm{pH}$ 7.5), $150 \mathrm{mM} \mathrm{NaCl}, 1 \%$ Triton $\mathrm{X}-100,1 \%$ sodium desoxycholate, $0.1 \%$ SDS, $1 \mathrm{mM}$ EDTA, $100 \mathrm{mM} \mathrm{NaF}, 1 \mathrm{mM}$ benzamine, $1 \mathrm{mM}$ PMSF, and $1 \mathrm{mM} \mathrm{Na3VO} 4)$. Collected lysates were cleared for $2 \mathrm{~min}$ at $8,000 \times g$ and protein amounts were measured with a Bradford assay using a BioRad Novapath microplate reader. Equal amounts of protein were fractionated on 10 or $15 \%$ gels, after which they were electrophoretically transferred to PVDF membranes (Boehringer-Mannheim, Indianapolis, IN) according to standard procedures. The membranes were blocked with $2 \%$ BSA in PBS containing $0.1 \%$ Tween-20 (Sigma), prior to incubation for $1 \mathrm{~h}$ with primary antibodies. After washing, the membranes were incubated for $1 \mathrm{~h}$ with secondary antibodies, washed again, and immunoreactivity was detected using ECL reagents (Perkin-Elmer).

\section{Microscopy}

Cell morphology in tissue-culture plates was visualized using

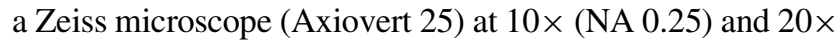
(NA 0.3) magnification. Images were captured on a CCD camera (Axiocam MRC), using Mr. Grab 1.0 software (Zeiss). Time-lapse video microscopy was performed on a Widefield CCD system using a $10 \times$ dry lens objective (Carl Zeiss MicroImaging, and images were captured every $15 \mathrm{~min}$ at $37^{\circ} \mathrm{C}$ and $5 \% \mathrm{CO}_{2}$. For immunofluorescence, cells on coverslips were fixed in $4 \%$ paraformaldehyde (PFA) in PBS for at least $15 \mathrm{~min}$, after which they were permeabilized with $0.5 \%$ Triton X-100. For BrdU stainings, the nuclei were subsequently denatured with $2 \mathrm{~N} \mathrm{HCl}$ for $30 \mathrm{~min}$ at $37^{\circ} \mathrm{C}$. After washing twice with PBS, cells were blocked in $50 \mathrm{mM}$ glycin in PBS for at least $10 \mathrm{~min}$, and washed twice with $0.2 \%$ gelatin in PBS (PBG). Subsequently, they were incubated with primary antibodies for $1 \mathrm{~h}$, washed three times with PBG, and incubated with secondary antibodies for $1 \mathrm{~h}$. Cells were then washed again three times with PBG, and once with PBS containing DAPI. Coverslips were mounted in Mowiol supplemented with DABCO (Calbiochem), and analyzed on a confocal microscope using $20 \times$ (NA 0.7) dry, $40 \times$ (NA 1.25), and 63× (NA 1.32) oil objectives (Leica). Images were acquired with AxioVision software (Carl Zeiss
MicroImaging), and processed using ImageJ and Adobe Photoshop software. Combined DAPI-phase/contrast images were captured on a Zeiss AxioObserver Z1 inverted microscope equipped with a cooled CCD-camera (Hamamatsu ORCA AG) using AxioVision software.

\section{BrdU/EdU labeling and quantification}

Synchronized cells were released in fresh medium containing $\operatorname{BrdU}(10 \mu \mathrm{M})$ in 96 -well plates at a density of $1 \times 10^{4}$ cells per well, and treated with the inhibitors at the indicated time-points. The cells were fixed $14 \mathrm{~h}$ after mitosis, and BrdU incorporation was determined using the Cell Proliferation, Enzyme-linked Immunosorbent Assay (ELISA) kit (Boehringer-Mannheim), according to the manufacturer's instructions. Absorbance was measured on a Bio-Rad Novapath microplate reader 5 min after substrate addition. In each experiment, cells supplemented with BrdU were fixed before $\mathrm{S}$-phase ( $5 \mathrm{~h}$ after mitosis) as a negative control. Independent experiments were performed with six samples for each condition, and each experiment was repeated at least three times. Incorporation of BrdU was also analyzed by immunofluorescence, by incubating cells on coverslips with $10 \mu \mathrm{M}$ BrdU for the indicated time-points. Cells were then fixed, and incorporated BrdU was detected as described above. Alternatively, cells were incubated on coverslips with $10 \mu \mathrm{M}$ EdU, and EdU incorporation was visualized using the Click-iT EdU imaging kit (Invitrogen) followed by confocal microscopy, according to the manufacturers' instructions.

Analysis of cell spreading, bi-nucleation, and nuclear cyclin D

To determine the cell surface area, synchronized cells were seeded in tissue-culture plates, treated as indicated, and fixed with $4 \%$ PFA at appropriate time-points. Phase/ contrast images were acquired as described, and the cell area of $\sim 100$ cells per condition was determined using ImageJ software. To determine the bi-nucleation index, synchronized cells were seeded on coverslips or tissueculture plates and treated as indicated, after which they were washed and released in fresh medium for $1 \mathrm{~h}$, fixed, and labeled with DAPI ( $5 \mu \mathrm{g} / \mathrm{ml})$. Phase/contrast and DAPI images were acquired from multiple fields, and in each independent experiment, bi-nucleation was determined for 300 cells. To quantify nuclear cyclin D, synchronized cells were plated on coverslips and treated for the indicated time-points, after which cyclin D1/D2 and nuclei were stained for confocal microscopy as described above. Images were acquired from multiple fields using the same settings, and cyclin $\mathrm{D}(+)$-nuclei were quantified with ImageJ from $\sim 250$ cells per experiment. 


\section{Results}

Disruption of the actin cytoskeleton in G1-phase reverses post-mitotic cell spreading and focal adhesion assembly

Here we employ the mitotic shake-off method to collect cells in cytokinesis from asynchronously growing cell cultures. Released cells reattach to the substratum within $15 \mathrm{~min}$ and most of them complete cytokinesis within $1 \mathrm{~h}$ after synchronization, whereafter cell spreading increases progressively throughout G1-phase (Fig. 1a). Whereas D-type cyclins are expressed in mitotic cells and throughout the entire G1-phase, expression of S-phase promoting cyclin $\mathrm{A}$ is induced about $5 \mathrm{~h}$ after mitosis, and the G2/M-phase cyclin B1 becomes detectable from $10 \mathrm{~h}$ after mitosis (Fig. 1b). The population undergoes the next cytokinesis approximately $16 \mathrm{~h}$ after synchronization (data not shown). The induction of cyclin A expression marks the onset of S-phase, and progression to S-phase requires the sustained activity and nuclear translocation of $\mathrm{p} 44 / \mathrm{p} 42$ MAPK, as these events are blocked using UO126, an inhibitor of the MAPK pathway (Fig. 1c, d) [33].

To investigate whether cytoskeletal organization and cell spreading are required for cell cycle progression in $\mathrm{G} 1$ phase in cycling N2A cells, we used the actin-destabilizing
A
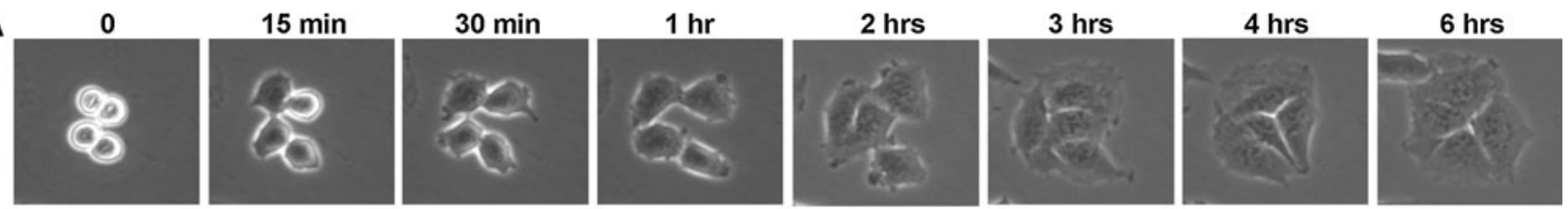

B

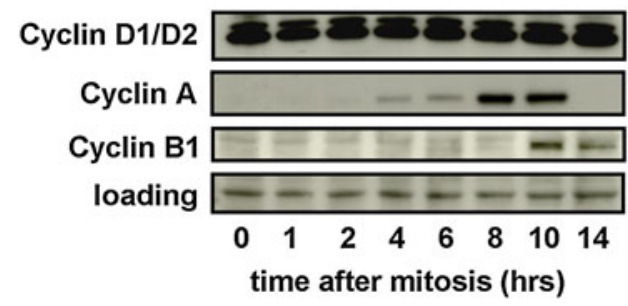

E

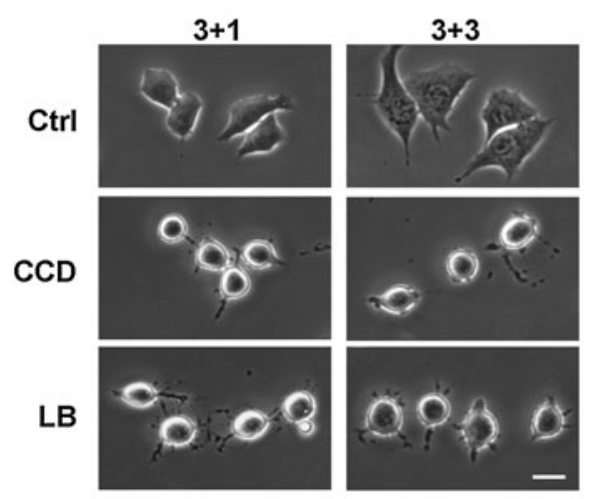

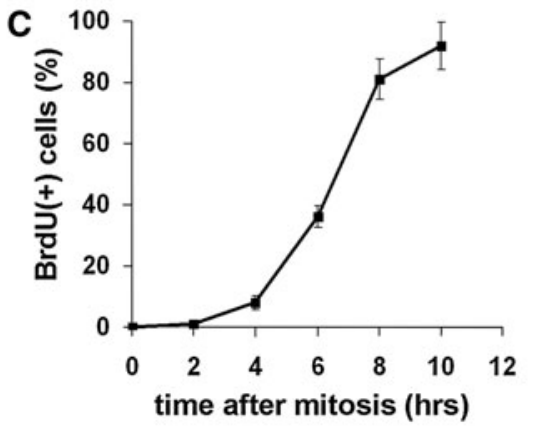

$\mathbf{F}$

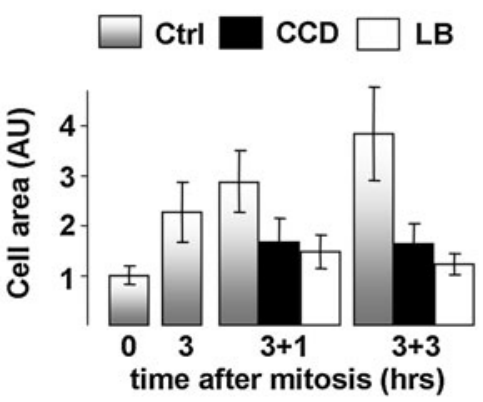

D

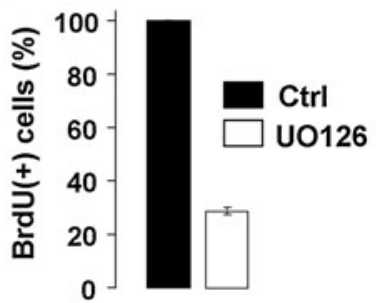

Fig. 1 Disruption of actin stress fibers in G1-phase causes cell rounding and FA disassembly. a Stills from a time-lapse movie showing N2A cells undergoing cytokinesis and post-mitotic cell spreading. b N2A cells were synchronized by mitotic shake-off and released in fresh medium. Cells were lysed at the indicated timepoints and the sequential expression of cyclin D1/D2, cyclin A, and cyclin B1 was determined by Western blotting. c N2A cells were synchronized by mitotic shake-off and released in the presence of $10 \mu \mathrm{M}$ BrdU. Progression into S-phase was determined at the indicated time-points by analyzing BrdU incorporation by immunofluorescence. d Progression from mitosis to S-phase is largely prevented by inhibition of the MAPK pathway with the inhibitor
UO126 $(20 \mu \mathrm{M})$. e N2A cells were synchronized by mitotic shake-off and released in fresh medium. After $3 \mathrm{~h}$, cells were either left untreated (upper panel), treated with $500 \mathrm{ng} / \mathrm{ml} \mathrm{CCD} \mathrm{(mid} \mathrm{panel)} \mathrm{or}$ $100 \mathrm{ng} / \mathrm{ml} \mathrm{LB}$ (lower panel), and photographed at 1 or $3 \mathrm{~h}$ thereafter. Bar $10 \mu \mathrm{m}$. f Cell area was determined at the indicated time-points from phase-contrast images using ImageJ, and expressed relative to the cell area of mitotic cells. $A U$ arbitrary units. $\mathbf{g ~ N} 2 \mathrm{~A}$ cells were synchronized by mitotic shake-off and treated with $500 \mathrm{ng} / \mathrm{ml} \mathrm{CCD} \mathrm{or}$ $100 \mathrm{ng} / \mathrm{ml} \mathrm{LB} 3 \mathrm{~h}$ thereafter. Cells were fixed after $3 \mathrm{~h}$ of incubation and the nuclei (blue), F-actin (red), and vinculin (green) were visualized with confocal microscopy. Bar $10 \mu \mathrm{m}$ 
drugs cytochalasin D (CCD) and latrunculin B (LB). Both drugs favor depolymerization of actin filaments but they act by distinct mechanisms; whereas CCD caps the growing ends of actin polymers, LB sequesters actin monomers. Mitotic cells were allowed to re-adhere and spread on FNcoated dishes in fresh medium with serum, after which they were treated with $500 \mathrm{ng} / \mathrm{ml} \mathrm{CCD}$ or $100 \mathrm{ng} / \mathrm{ml} \mathrm{LB}$ at progressive time-points in G1-phase. Post-mitotic cell spreading was quantified by measuring the apparent surface area from phase-contrast images. Cell spreading of untreated cells increased from mitosis into $\mathrm{G} 1$, and treatment of spread cells in G1-phase (from $3 \mathrm{~h}$ after mitosis) with either $C C D$ or $L B$ for $1 \mathrm{~h}\left(\mathrm{M}+3 \mathrm{~B}_{1}\right)$ or $3 \mathrm{~h}$ $\left(\mathrm{M}+3 \_3\right)$ induced cell rounding (Fig. 1e, f). We next
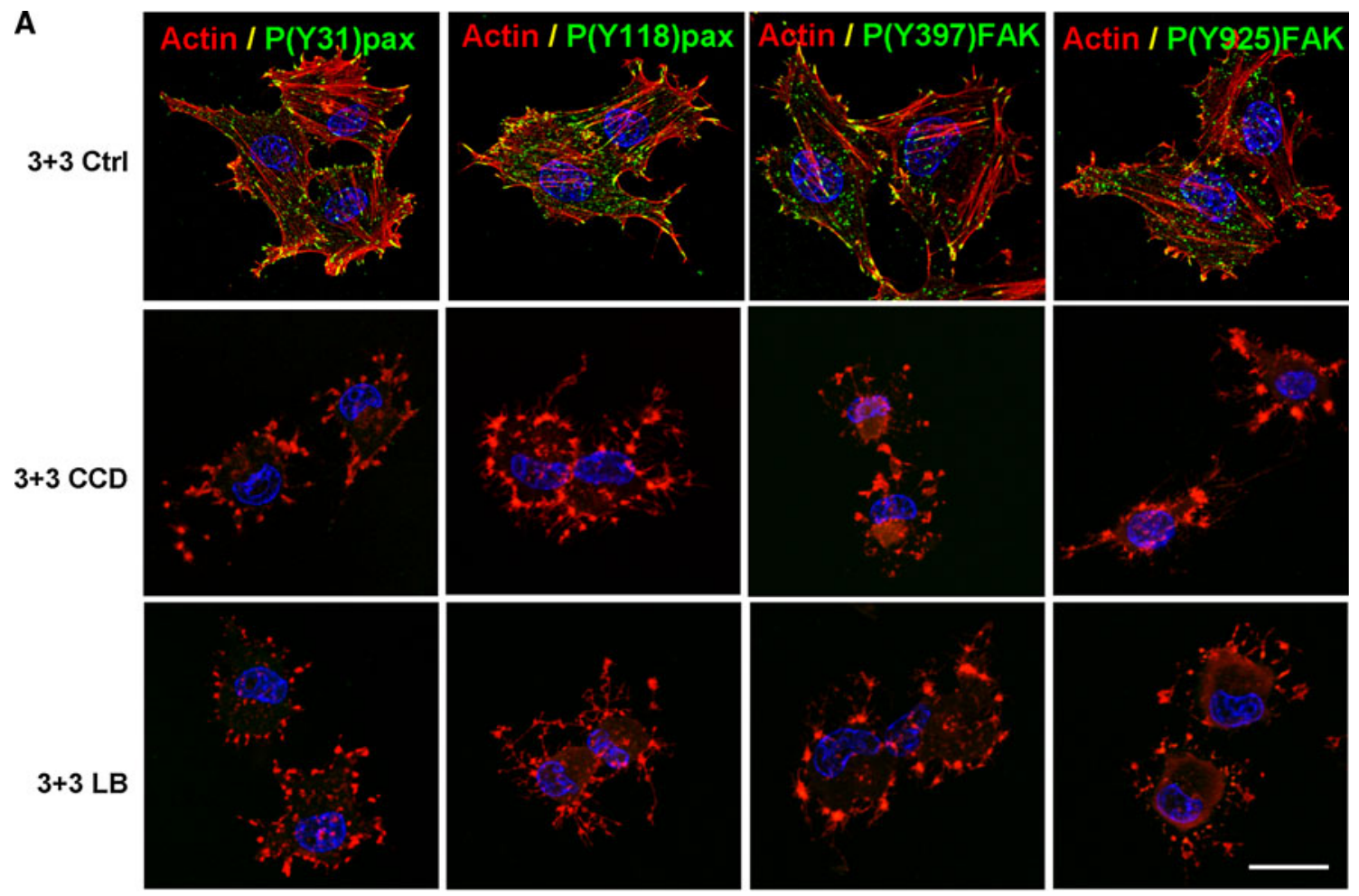

B

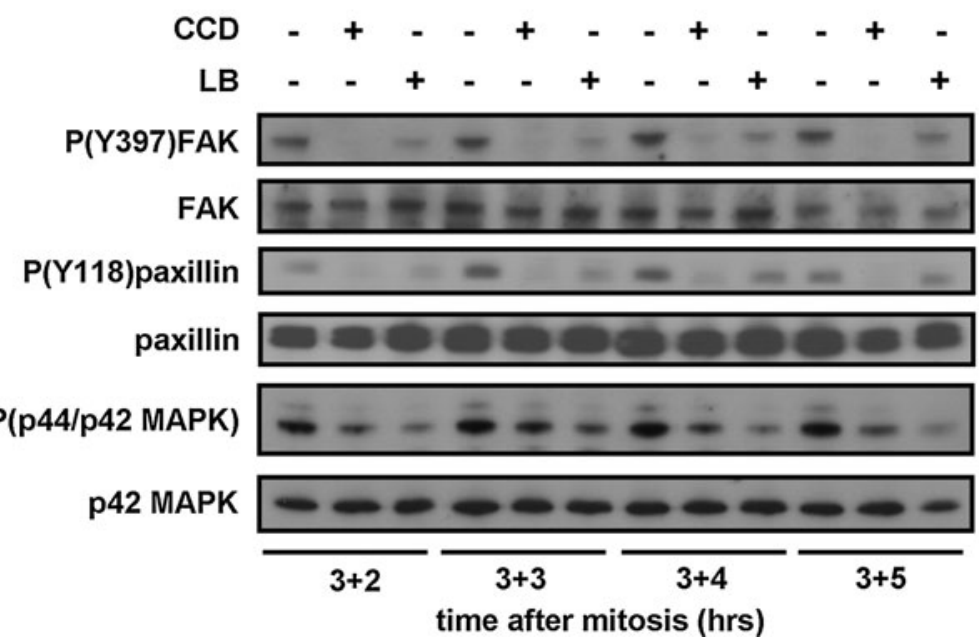

Fig. 2 Disruption of actin stress fibers in G1-phase inhibits integrin signaling and growth factor signaling. a N2A cells were synchronized by mitotic shake-off, released in fresh medium, and $3 \mathrm{~h}$ after synchronization they were either left untreated (top row), treated with $500 \mathrm{ng} / \mathrm{ml} \mathrm{CCD}$ (middle row), or treated with $100 \mathrm{ng} / \mathrm{ml} \mathrm{LB}$ (bottom row). Cells were fixed $3 \mathrm{~h}$ later and the nuclei (blue), F-actin (red), and phosphorylation of FAK and paxillin at the indicated residues (green) were visualized with confocal microscopy. Bar $10 \mu \mathrm{m}$. b N2A cells were synchronized by mitotic shake-off and $3 \mathrm{~h}$ later treated as described. Cells were lysed 2, 3, 4, and $5 \mathrm{~h}$ thereafter and autophosphorylation of (Y397)FAK, phosphorylation of (Y118)paxillin, and phosphorylation of p44/p42 MAPK, as well as total levels of FAK, paxillin, and p42 MAPK were investigated by Western blotting 
A
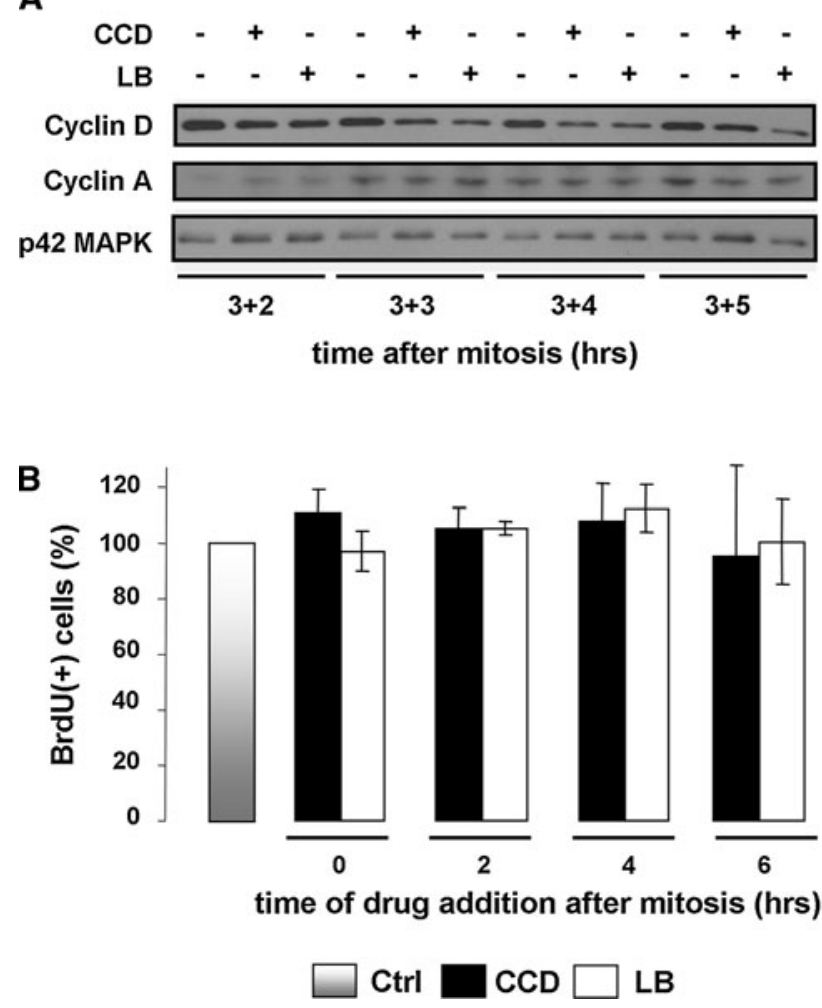

Fig. 3 Disruption of actin stress fibers in G1-phase does not inhibit S-phase entry in continuously cycling N2A cells. a N2A cells were synchronized by mitotic shake-off and $3 \mathrm{~h}$ later treated as described. Cells were lysed 2, 3, 4, and $5 \mathrm{~h}$ thereafter and expression of cyclin D and cyclin $\mathrm{A}$ was investigated by Western blotting (p42 MAPK = loading control). b N2A cells were synchronized by shake-off, released in fresh medium containing $10 \mu \mathrm{M}$ BrdU, and CCD or LB were added at the indicated time-points. After $14 \mathrm{~h}$, cells were fixed

analyzed cytoskeletal organization and FA assembly in G1phase, using the filamentous actin (F-actin)-binding compound phalloidin and an antibody against the FA marker vinculin, which is involved in linking integrins to the actin cytoskeleton. Actin stress fibers associated with FAs were observed in spread cells in G1-phase, and treatment with either drug induced FA loss and dissolution of actin stress fibers, whereas some F-actin was retained in membrane structures left behind after cell rounding (Fig. 1g). Thus, treatment with CCD or LB in G1-phase cells disrupts the normal organization of the actin cytoskeleton, and induces cell rounding and FA disassembly.

Disruption of the actin cytoskeleton in G1-phase inhibits integrin signaling and growth factor signaling

Integrin-mediated re-adhesion and cell spreading after mitosis triggers the auto-phosphorylation of one of the major kinases in FAs, focal adhesion kinase (FAK), on Y397 [29, 37]. Autophosphorylation of FAK triggers the recruitment of Src, which subsequently phosphorylates
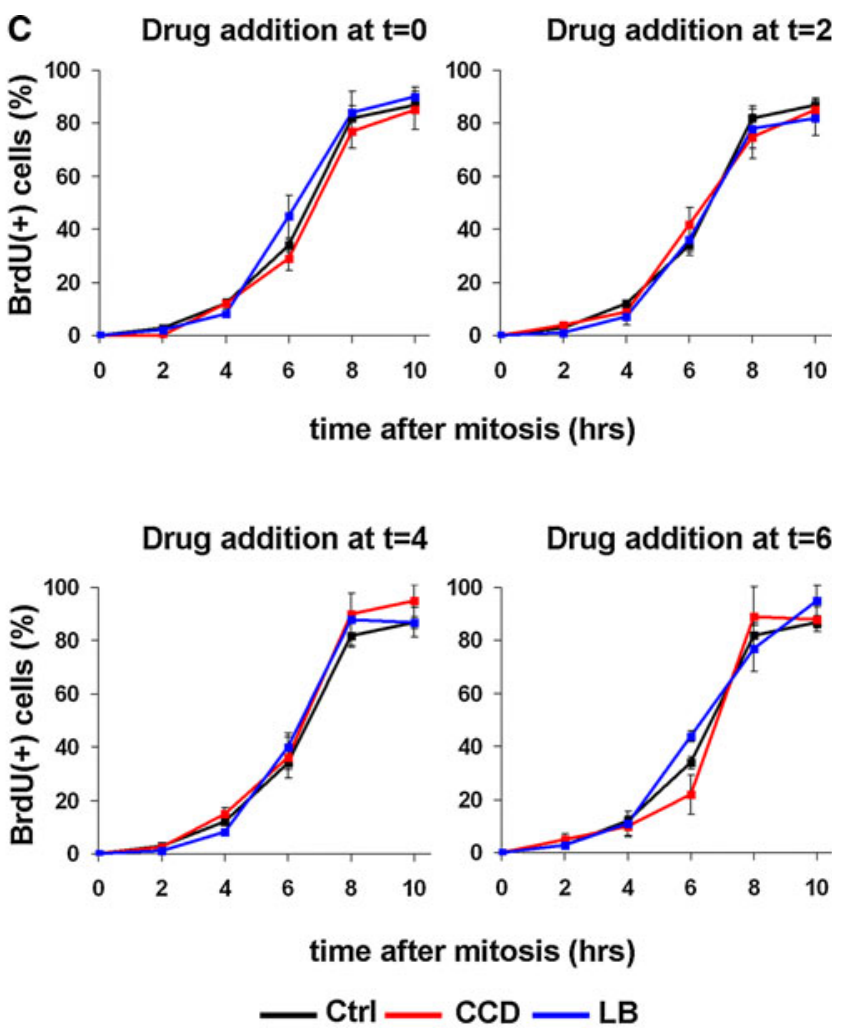

and BrdU incorporation was determined with an ELISA. Incorporation in untreated cells was set to $100 \%$. The graph represents the averages \pm SEM from three independent experiments. $\mathbf{c}$ Mitotic N2A cells were released on coverslips in fresh medium containing $10 \mu \mathrm{M}$ BrdU, and CCD or LB were added at $0,2,4$, or $6 \mathrm{~h}$ after mitosis. Incorporation of $\mathrm{BrdU}$ at the indicated time-points was determined by immunofluorescence

FAK on Y925. In turn, FAK interacts with the signal transduction adapter protein paxillin, and induces its phosphorylation at Y118 and Y31. To determine whether cytoskeletal disruption and cell rounding induced by $\mathrm{CCD}$ or LB in G1-phase cells affects integrin signaling, we treated G1-phase cells $3 \mathrm{~h}$ after mitosis with the actin inhibitors, and investigated the phosphorylation of paxillin and FAK by immunofluorescence and Western blotting. Whereas paxillin phosphorylation on Y118 and Y31 and FAK phosphorylation on Y397 and Y925 were clearly visible in FAs in untreated cells, reduced or no phosphorylation on these residues was observed in the CCD- or LBtreated cells (Figs. 2a, b), indicating that disruption of the actin cytoskeleton in G1-phase inhibits integrin-mediated signaling events. Because integrin-mediated cell spreading and organization of the actin cytoskeleton support growth factor signaling, we next investigated whether disruption of actin stress fibers in G1-phase cells also impedes growth factor-induced MAPK phosphorylation. MAPK phosphorylation in untreated cells was detected throughout G1, but was considerably reduced upon treatment with $\mathrm{CCD}$ or $\mathrm{LB}$ 
(Fig. 2b), confirming that growth factor signaling in G1 depends on intact actin filaments. Taken together, these results indicate that disruption of the actin cytoskeleton and cell spreading in G1-phase cells attenuates both integrin signaling and growth factor signaling.

G1/S-phase progression in cycling N2A and CHO cells is not inhibited by disruption of the actin cytoskeleton and cell spreading

We next examined whether cell cycle progression into S-phase was affected by the disruption of actin filaments. First, we treated cells with the drugs starting at $3 \mathrm{~h}$ after mitosis until well into $\mathrm{S}$-phase ( $8 \mathrm{~h}$ post-mitosis), and then analyzed the expression of cyclin D by Western blotting. Consistent with previous observations, a progressive decline in cyclin D levels was observed in CCD- or LBtreated cells, but expression was not abolished completely (Fig. 3a). Moreover, cytoskeletal disruption did also not impair the induction of cyclin A expression (Fig. 3a). We then analyzed whether these cells progressed through $\mathrm{S}$-phase by releasing synchronized cells in medium containing the thymidine analogue BrdU, and measuring BrdU incorporation $14 \mathrm{~h}$ after mitosis using an ELISA. To assess whether there is a specific time-frame in G1 that requires cytoskeletal integrity, CCD or LB were added at $0,2,4$, or $6 \mathrm{~h}$ after synchronization. Interestingly, drug addition at neither time-point decreased BrdU incorporation as compared to untreated cells, indicating that also in the presence of the drugs, the entire cell population had entered and completed S-phase (Fig. 3b). In contrast, disruption of the actin cytoskeleton did prevent $\mathrm{S}$-phase entry in quiescent cells that were serum-stimulated to re-enter the cell cycle (Suppl. Fig. 1), as has been documented extensively in a variety of cell types $[7,9,10,12,13,15]$. We then investigated whether the drugs caused a delay or acceleration in the rate of progression from mitosis to S-phase, by analyzing BrdU incorporation at several time-points for up to $10 \mathrm{~h}$ after mitosis. BrdU incorporation was identical in all conditions, suggesting that disruption of the cytoskeleton does not affect the rate of G1-phase progression (Fig. 3c).

To exclude that the observed phenomenon is restricted to $\mathrm{N} 2 \mathrm{~A}$ cells, we next analyzed the same events in $\mathrm{CHO}$ cells isolated by mitotic shake-off. Similar to in N2A cells, incubation of spread post-mitotic $\mathrm{CHO}$ cells with $\mathrm{CCD}$ or LB induced cell rounding and disruption of stress fibers and FAs (data not shown). Correspondingly, FAK autophosphorylation and MAPK phosphorylation were also reduced in CHO cells (Suppl. Fig. 2A). However, as in N2A, progression to S-phase was not prevented, as indicated by expression levels of cyclin A and BrdU incorporation, and no actin cytoskeleton-dependent time-window for G1/Sphase progression was detected (Suppl. Fig. 2B). Together, these results suggest that disruption of the actin cytoskeleton during G1-phase does not inhibit progression from mitosis to S-phase in cycling N2A and CHO cells, despite decreased integrin signaling and growth factor-stimulated MAPK phosphorylation.

G1/S-phase progression in the absence of cell spreading or stress fibers depends on MAPK signaling

The previous sections have shown that in the absence of cell spreading, actin stress fibers or detectable FAs, cycling $\mathrm{N} 2 \mathrm{~A}$ and $\mathrm{CHO}$ cells can progress from mitosis to S-phase, despite strongly reduced MAPK activity. Because normal progression from mitosis to $\mathrm{S}$-phase requires sustained MAPK activity throughout G1-phase (Fig. 1d) [33], we next explored the cross-talk between MAPK signaling and cytoskeletal organization, and the requirement for MAPK activity in cytoskeleton-disrupted cells. We therefore synchronized N2A cells by mitotic shake-off and released them in medium containing $500 \mathrm{ng} / \mathrm{ml} \mathrm{CCD,} 100 \mathrm{ng} / \mathrm{ml}$ $\mathrm{LB}$, or $20 \mu \mathrm{M}$ UO126. Western blotting for phosphorylated p44/p42 MAPK levels revealed that UO126 inhibited MAPK activity much more rigorously than CCD and LB, as phospho-MAPK was virtually absent after prolonged incubation with UO126, even on overexposed blots (Fig. 4a). In contrast, P(Y397)FAK was strongly inhibited by CCD or LB but not by UO126, indicating that integrindependent events do not require MAPK activity (Fig. 4a) Consistent with this notion, cell spreading, stress fiber formation, or FA assembly (visualized using an antibody against phosphotyrosines) were not affected by treatment with UO126 (Fig. 4b). We then incubated cells in the presence of CCD or LB together with UO126, and determined whether these cells progressed into S-phase by measuring BrdU incorporation as described above. Intriguingly, the addition of UO126 strongly prevented BrdU incorporation, indicating that cell cycle progression in cytoskeleton-disrupted cells critically depends on MAPK activity (Fig. 4c). Taken together, these data indicate that MAPK activity is not required for cell spreading, cytoskeletal organization, and integrin signaling. However, MAPK is crucial for cell cycle progression, both in untreated and cytoskeleton-disrupted cells.

Cycling N2A cells progress through G2- and M-phase in the absence of cell spreading, actin stress fibers, or focal adhesions

We next investigated whether cell cycle progression proceeded after S-phase through G2 and the next M-phase. For this purpose, synchronized cells were treated with the actin inhibitors at several time-points in G1 as described above, and the expression of the $\mathrm{G} 2 / \mathrm{M}$ markers cyclin B1, which 


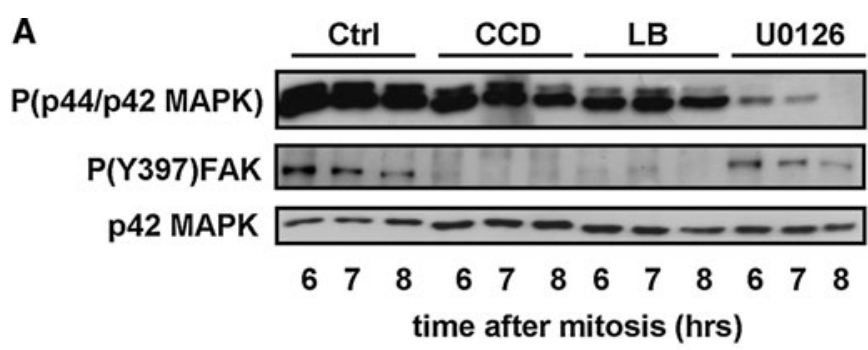

B
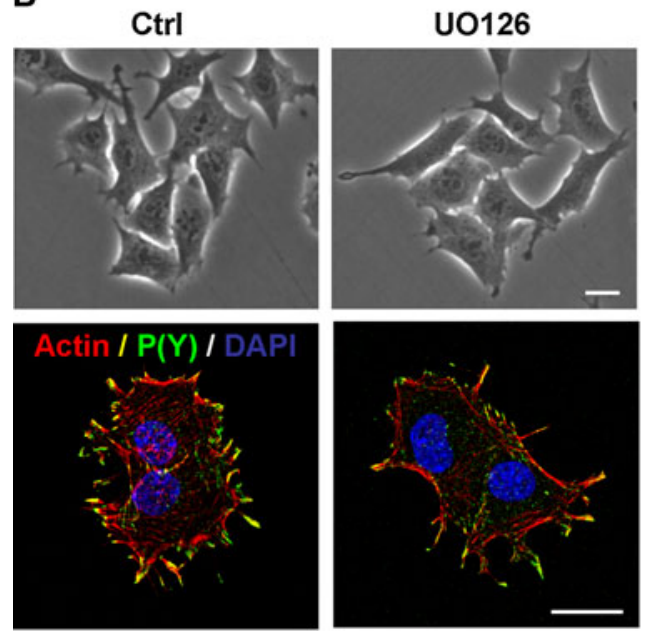

C

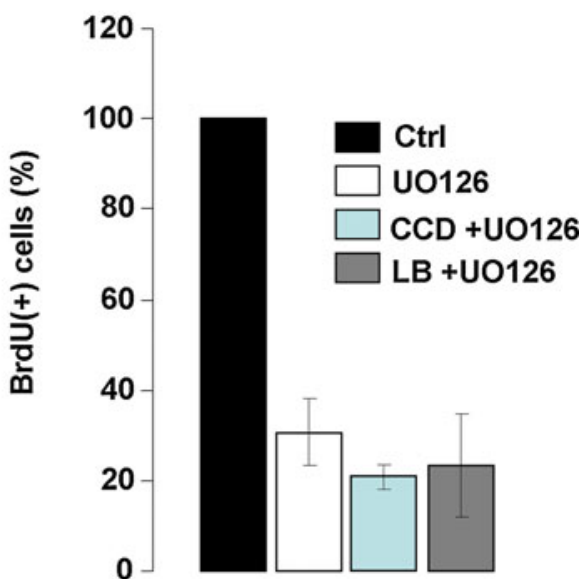

Fig. 4 Progression through G1-phase in the absence of cell spreading and stress fibers depends on MAPK signaling. a N2A cells were synchronized by shake-off and released in fresh medium supplemented with $500 \mathrm{ng} / \mathrm{ml} \mathrm{CCD}, 100 \mathrm{ng} / \mathrm{ml} \mathrm{LB}$, or $20 \mu \mathrm{M}$ UO126. Cells were lysed at the indicated time-points after synchronization, and phosphorylation of p44/p42 MAPK and (Y397)FAK were investigated by Western blotting (p42 MAPK = loading control). b Top phase-contrast images of N2A cells that were incubated for up to $5 \mathrm{~h}$ after mitosis in the absence (left) or the presence of $20 \mu \mathrm{M}$ UO126 (right). Bar $10 \mu \mathrm{m}$. Bottom; Confocal images showing F-actin (red),

together with cdk1 promotes entry into mitosis, and securin, an essential modulator of metaphase-anaphase transition, was determined by Western blotting. Intriguingly, both cyclin B1 and securin were detectable from $10 \mathrm{~h}$ after mitosis in all conditions, suggesting that cells with disrupted cytoskeletons progress normally though G2-phase and complete their whole cycle (Fig. 5a and data not shown). We then incubated synchronized cells for the length of more than an entire cell cycle with the actin inhibitors. Suppression of actin polymerization during mitosis leads to cleavage failure, creating bi-nucleated cells. We therefore used bi-nucleation as a parameter for cell cycle completion in the presence of CCD or LB. After $20 \mathrm{~h}$ of incubation, cells were still rounded, indicating that the inhibitors were still functional (data not shown). The drugs were then washed out, and the cells were allowed to recover for $1 \mathrm{~h}$ in fresh medium, in which cell spreading was resumed (Fig. 5b). Cell spreading was accompanied by de novo re-organization of the actin cytoskeleton into stress
FAs (visualized with an antibody against phosphotyrosines, green) and nuclei (blue) in N2A cells that were incubated for up to $5 \mathrm{~h}$ after mitosis in the absence (left) or the presence of $20 \mu \mathrm{M}$ UO126 (right). Bar $10 \mu \mathrm{m}$. c Mitotic N2A cells were released on coverslips in fresh medium containing either $20 \mu \mathrm{M}$ UO126 alone, $20 \mu \mathrm{M}$ UO126 and CCD $(500 \mathrm{ng} / \mathrm{ml})$, or $20 \mu \mathrm{M}$ UO126 and LB (100 ng/ml). BrdU incorporation was then determined $14 \mathrm{~h}$ later by immunofluorescence. The graph represents the averages from $\sim 300$ cells \pm SEM from three independent experiments

fibers, as well as FA assembly and integrin signaling, as judged by staining for phosphorylated (Y118)paxillin (Fig. 6). In line with the expression of cyclin $\mathrm{B} 1$ and securin, the vast majority of the CCD- and LB-treated N2A cells was bi-nucleated, confirming that they had indeed progressed through G2- and M-phase (Fig. 5b). Moreover, immunofluorescence analysis revealed that all bi-nucleated cells had incorporated BrdU (Suppl. Fig. 3). This is in line with the results obtained with the ELISAs, and reaffirms that the bi-nucleated cells have gone through an entire cycle. Intriguingly, nuclear localization of cyclin D was detected in bi-nucleated cells (Fig. 6). Nuclear import of cyclin D occurs in growth-committed cells in G1-phase and is necessary for passage of the restriction point, whereas its subsequent export and degradation in the cytoplasm is required during S-phase [38]. During the ongoing cell cycle, nuclear cyclin $\mathrm{D}$ is detectable starting $2 \mathrm{~h}$ after mitosis until the onset of S-phase ( $\sim 6 \mathrm{~h}$ after mitosis), whereafter nuclear cyclin D levels decrease (Suppl. Fig. 4). 
A

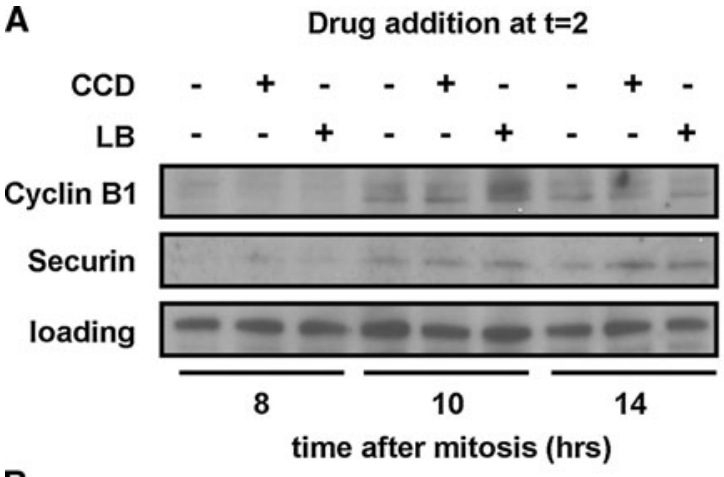

B

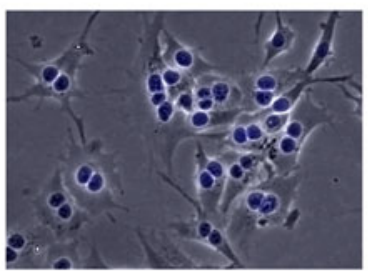

CCD_0

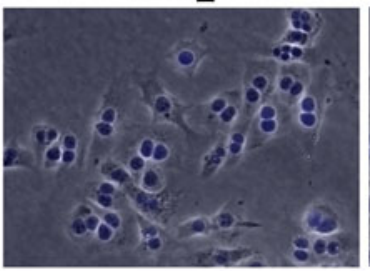

LB_0

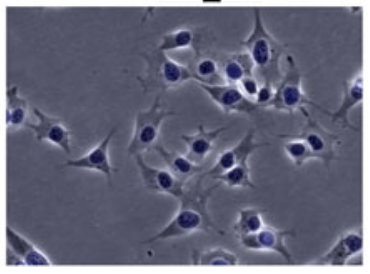

Ctrl

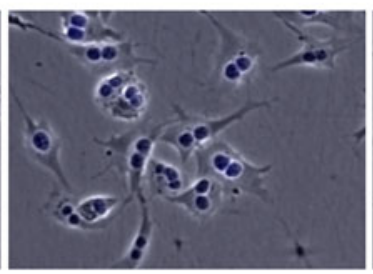

CCD_2

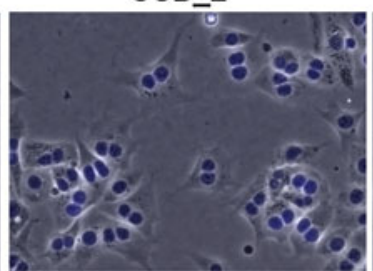

LB_2
๖

100

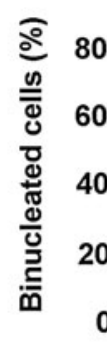

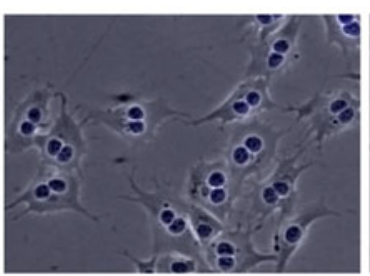

CCD_4

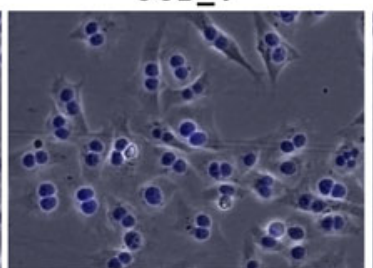

LB_4

8

10

time after mitosis (hrs)

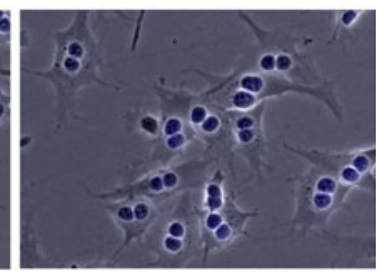

CCD_6

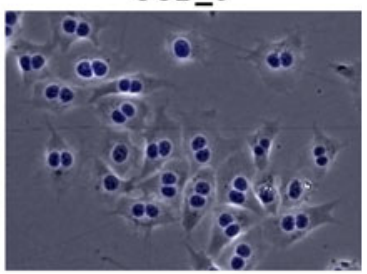

LB_6

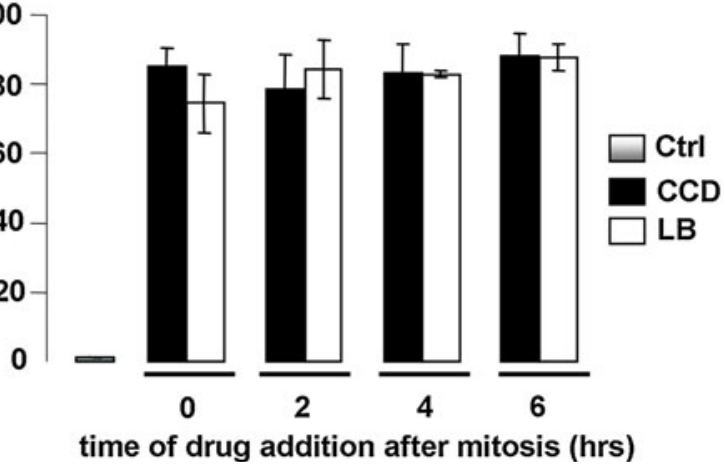

Fig. 5 Cycling N2A cells progress through G2- and M-phase in the absence of cell spreading or cytoskeletal integrity. a N2A cells were collected by shake-off and treated with CCD or LB at 2 or $4 \mathrm{~h}$ after synchronization. Cells were lysed at 8,10 , or $14 \mathrm{~h}$ after synchronization, and expression of cyclin B1 and securin were detected by Western blotting. b N2A cells were collected by shake-off and treated

Quantification of cyclin D-positive nuclei revealed that cyclin D accumulation in the nucleus of CCD- or LBtreated cells was similar to that in untreated cells (Fig. 7), suggesting that these cells not only completed an entire cycle, but even committed to a new one in the presence of the drugs. However, during prolonged treatment with the inhibitors over several days, the multi-nucleated population underwent massive apoptosis, possibly due to genomic instability (data not shown). Summarizing, the data with CCD or LB at the indicated time-points after synchronization. The drugs were washed away after $20 \mathrm{~h}$, after which the cells were released in fresh medium for $1 \mathrm{~h}$. They were then fixed, stained with DAPI, and the percentage of mono- and bi-nucleated cells was determined from $\sim 300$ cells per experiment. The graph represents the averages \pm SEM from three independent experiments

presented here show that $\mathrm{N} 2 \mathrm{~A}$ and $\mathrm{CHO}$ cells can progress through the continuous cell cycle in the absence of extensive cell spreading, stress fibers, or FAs.

Cycling GE $\beta 1$ cells do not require cell spreading, actin stress fibers, or focal adhesions

In the previous sections, we have shown that $\mathrm{FN}$-supported cell cycle progression in cycling $\mathrm{N} 2 \mathrm{~A}$ and $\mathrm{CHO}$ cells does 

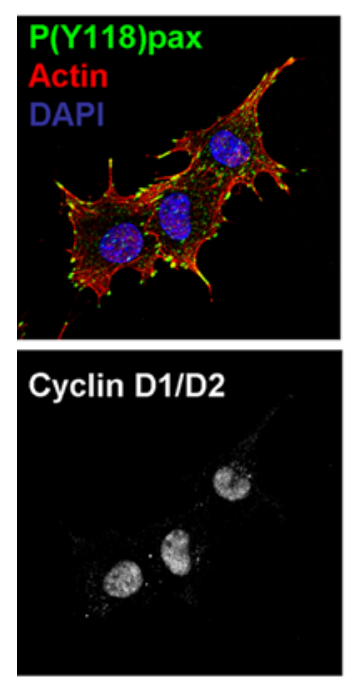

Ctrl
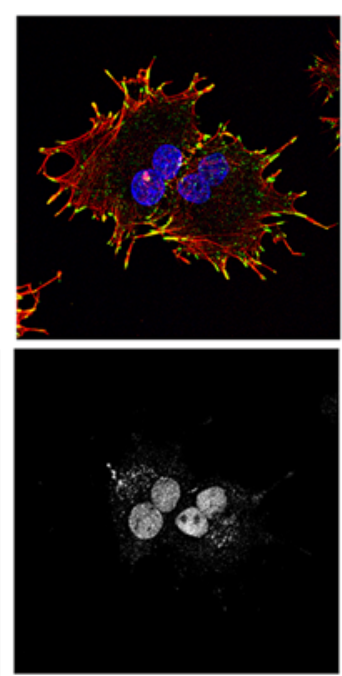

CCD_0
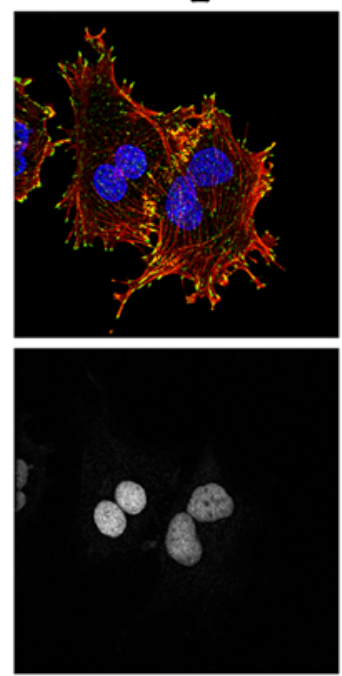

LB_0
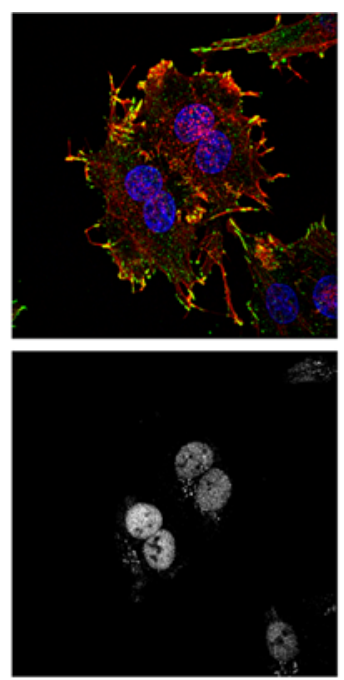

CCD_2
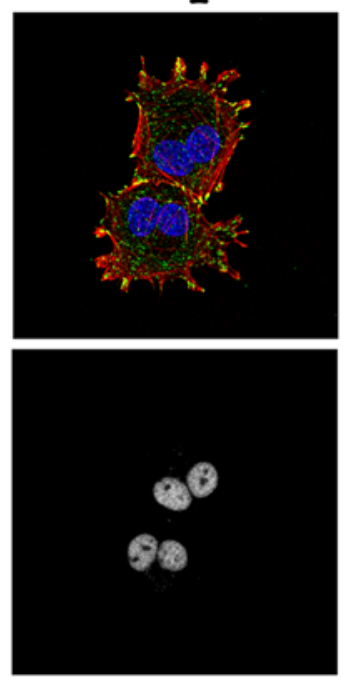

LB_2
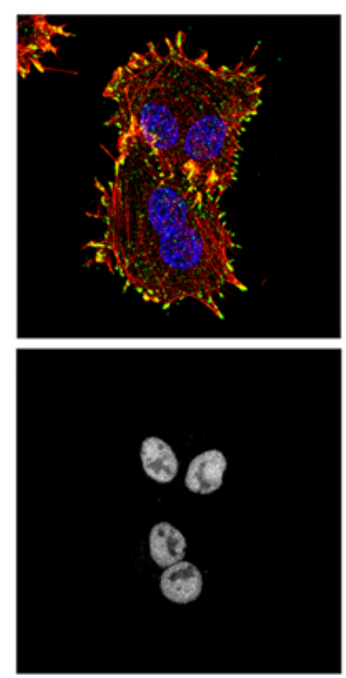

CCD_4
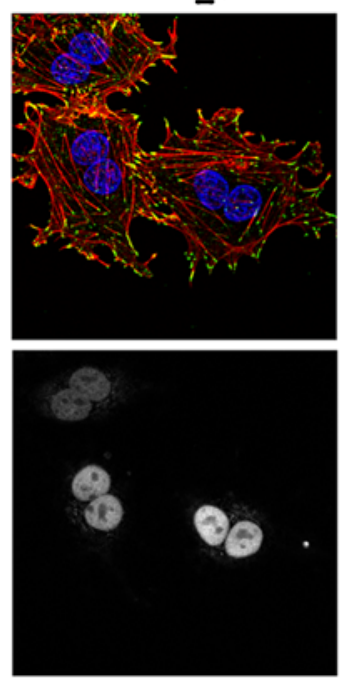

LB_4
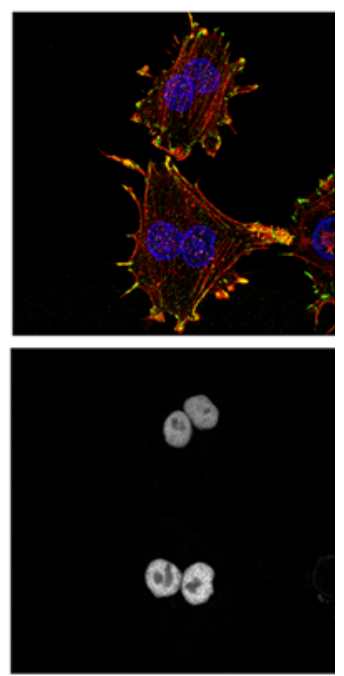

CCD_6
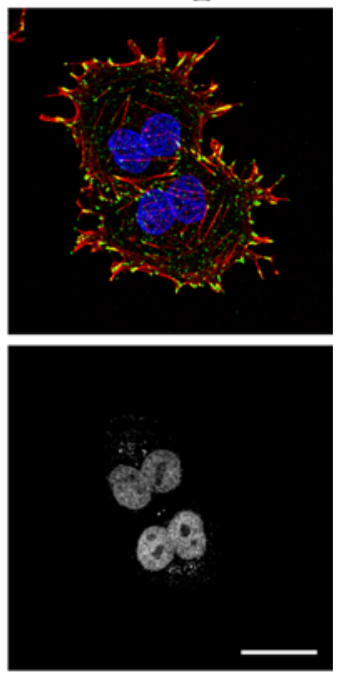

LB_6
Fig. 6 Cell spreading and actin stress fibers are dispensable for nuclear translocation of cyclin D1/D2 in cycling N2A cells. N2A cells were synchronized by shake-off and treated with CCD or LB at the indicated time-points after synchronization. After $20 \mathrm{~h}$, the drugs were washed away and the cells were fixed $1 \mathrm{~h}$ later, after which they

not depend on an intact cytoskeleton or cell spreading, which is in apparent contrast to studies using non-transformed capillary endothelial cells and fibroblasts, in which cell cycle re-entry from quiescence is inhibited upon disruption of the actin cytoskeleton [7-14]. The tensional requirements for cell cycle progression may differ between non-transformed and transformed cells. We therefore analyzed FN-supported cell cycle progression under the same conditions in GE $\beta 1$ cells, which predominantly express FN-binding integrin $\alpha 5 \beta 1$, and do not display typical hallmarks of oncogenic transformation (they do not grow without growth factors or in soft agar, and do not form tumors in mice unless transformed with oncogenic Ras) $[35,39,40]$. Mitotic GE $\beta 1$ cells were isolated by shake-off were processed for microscopy using phalloidin-TRITC and DAPI, as well as antibodies against cyclin D1/D2 and $\mathrm{P}(\mathrm{Y} 118)$ paxillin. Pictures were obtained on a confocal microscope. Top nuclei (blue), F-actin (red), $\mathrm{P}(\mathrm{Y} 118)$ paxillin (green). Bottom cyclin D1/D2. Bar $10 \mu \mathrm{m}$

and released on $\mathrm{FN}$, after which they were treated with CCD $(250 \mathrm{ng} / \mathrm{ml})$ or LB $(100 \mathrm{ng} / \mathrm{ml})$ at appropriate timepoints in G1. Cytoskeletal organization, FA assembly, and integrin-induced signaling events were visualized using phalloidin and an antibody against tyrosine-phosphorylated proteins. Post-mitotic GE $\beta 1$ cells resumed cell spreading and re-gained stress fibers and FAs within $2 \mathrm{~h}$, and cell spreading increased progressively thereafter (Fig. 8a). Treatment with either drug in G1-phase abolished actin stress fibers, cell spreading, FA assembly, and tyrosine phosphorylations within $1 \mathrm{~h}$ (Fig. 8a). We next investigated cell cycle progression in the presence of the inhibitors, by determining the bi-nucleation index as described above. Drugs were washed away $20 \mathrm{~h}$ after 


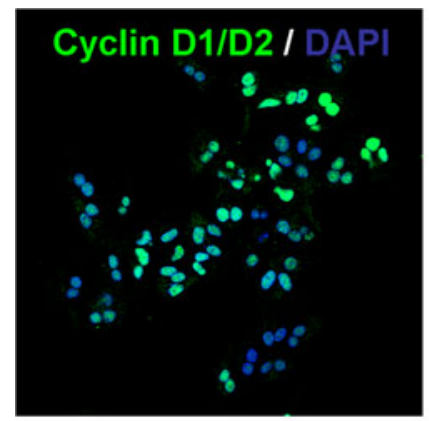

CCD_0

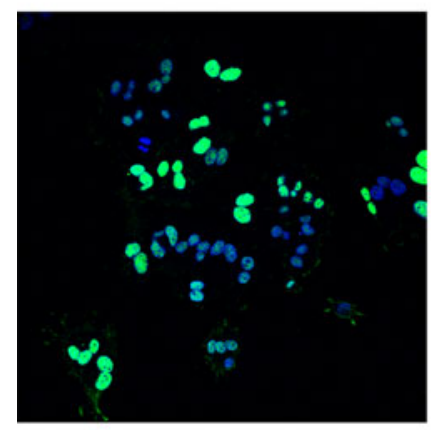

LB_0

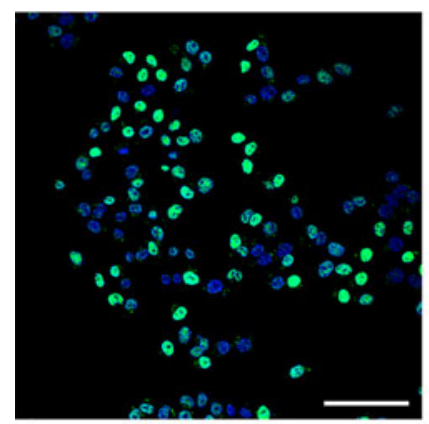

Ctrl

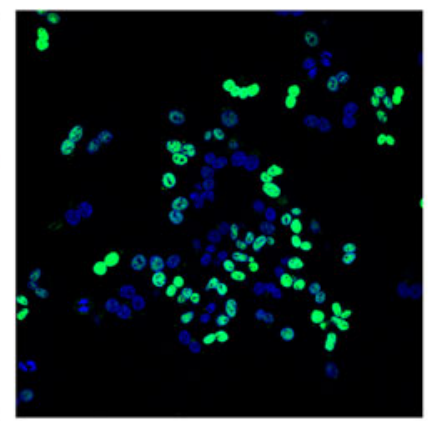

CCD_2

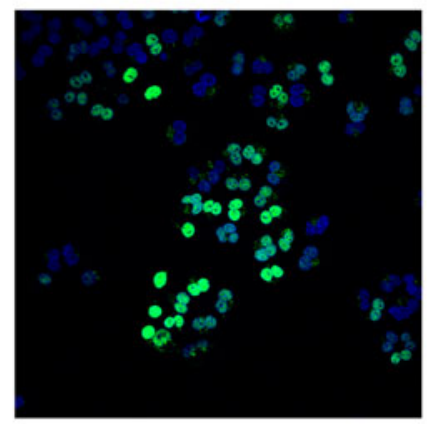

LB_2

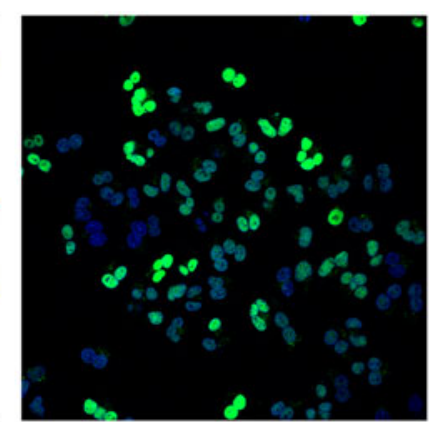

CCD_4

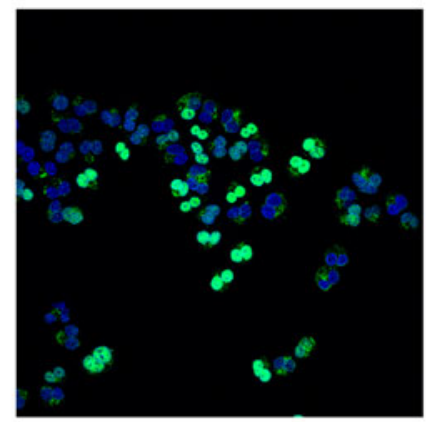

LB_4

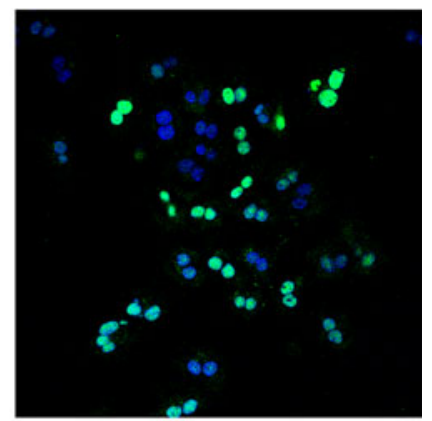

CCD_6

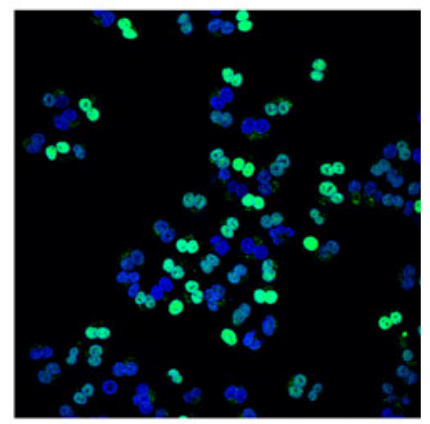

LB_6

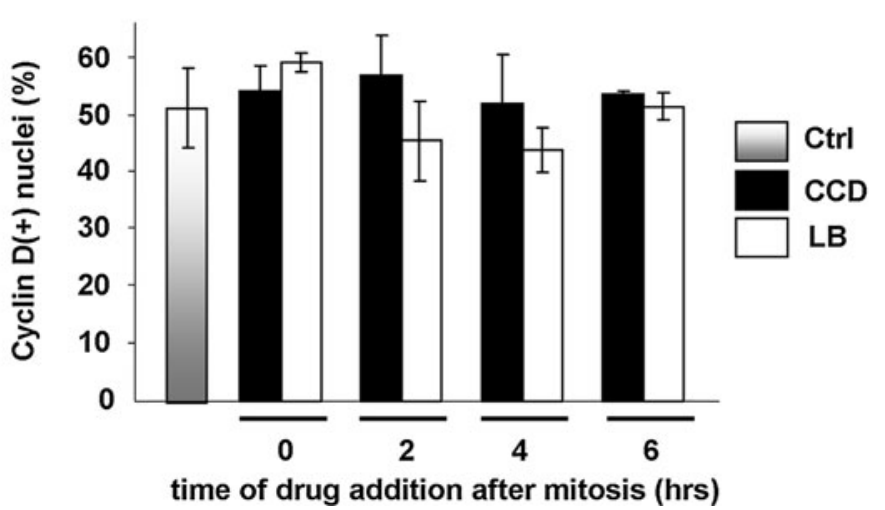

Fig. 7 Disruption of cytoskeletal integrity and cell spreading does not prevent entry into a new cell cycle. N2A cells were collected by shake-off and treated with CCD or LB at the indicated time-points after synchronization. After $20 \mathrm{~h}$, the cells were fixed and cyclin D1/ $\mathrm{D} 2$ (green) and the nuclei (blue) were visualized with confocal

mitosis, and cells were allowed to recover in fresh medium. A complete recovery of actin stress fibers, cell spreading, and FA assembly was observed $1.5 \mathrm{~h}$ after drug wash-out, and the vast majority of the cells appeared to have two nuclei (Fig. 8b). Indeed, bi-nucleation indices clearly show that disruption of the actin cytoskeleton at neither timepoint in G1-phase induced a cell cycle arrest (Fig. 8c). Taken together, these data show that similar to in N2A and $\mathrm{CHO}$ cells, cell cycle progression in cycling GE $\beta 1$ cells does not depend on actin stress fibers, FAs, or extensive cell spreading. microscopy. The percentage of cyclin $\mathrm{D}(+)$ cells was quantified using ImageJ from confocal images acquired with the same settings. For each condition, $\sim 250$ cells were analyzed and the graph represents the averages \pm SEM from three independent experiments. Bar $50 \mu \mathrm{m}$

\section{Discussion}

In this study, we investigated the requirements for FA assembly, cytoskeletal integrity, cell spreading, and MAPK activity in FN-supported progression through the ongoing cell cycle. Mitotic N2A and CHO cells were collected by shake-off and released on FN-coated dishes, after which post-mitotic actin stress fiber formation was abolished with pharmacological agents at progressive time-points during G1-phase. Cell spreading, FA assembly, and integrin signaling were disrupted by this treatment. Furthermore, 
A

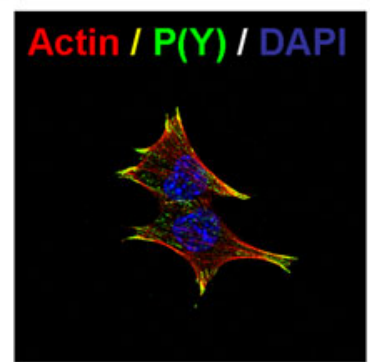

B

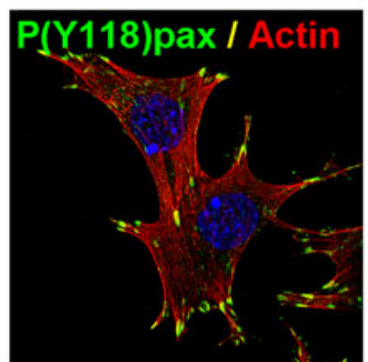

Ctrl

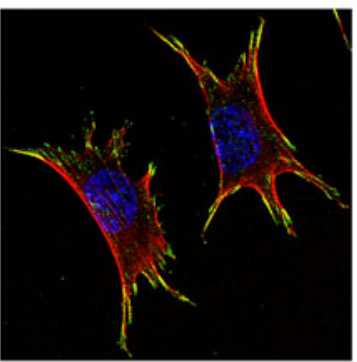

$M+4$

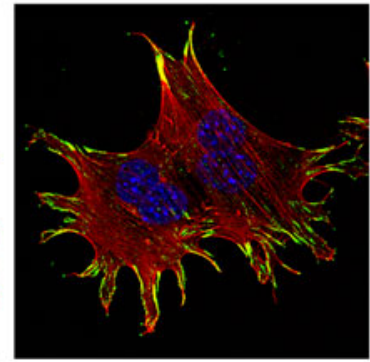

CCD_4

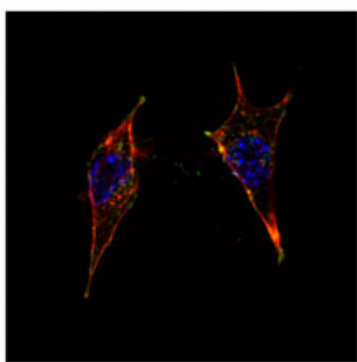

M+4_1CCD

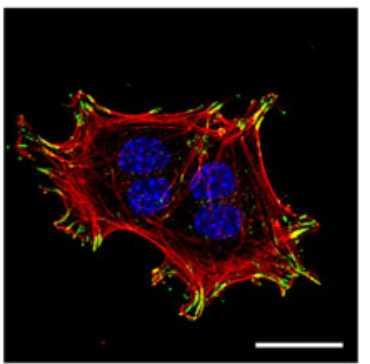

LB_4

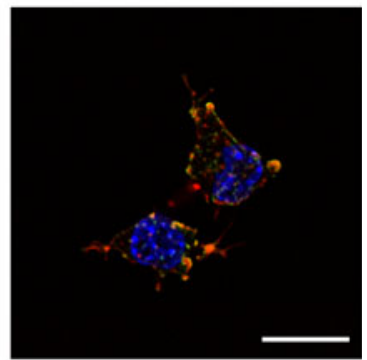

M+4_1LB

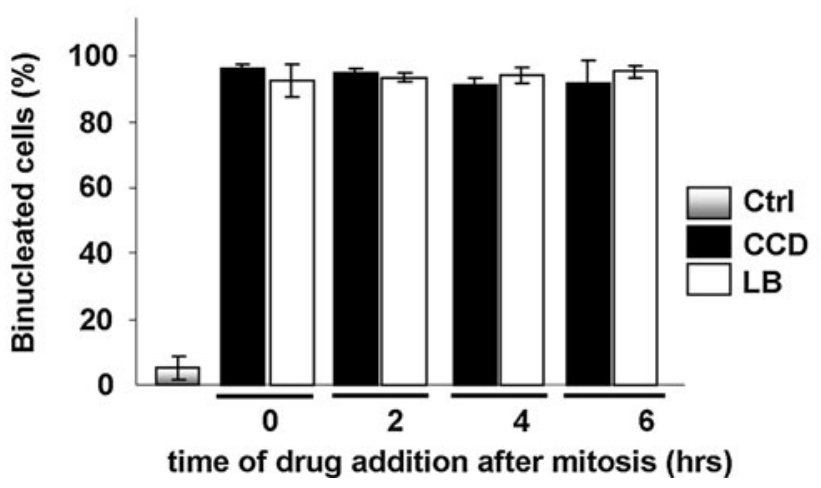

Fig. 8 Cell cycle progression in GE $\beta 1$ cells does not require cell spreading, actin stress fibers, or FAs. a GE $\beta 1$ cells were synchronized by mitotic shake-off, released in fresh medium on FN-coated coverslips, and then fixed in G1-phase at the indicated time-points. Alternatively, they were treated with CCD $(250 \mathrm{ng} / \mathrm{ml})$ or LB $(100 \mathrm{ng} / \mathrm{ml}) 3 \mathrm{~h}$ after mitosis, and fixed $1 \mathrm{~h}$ later. The nuclei (blue), F-actin (red), and FAs (stained with an antibody against phosphotyrosines; green) were visualized with confocal microscopy. Bar $10 \mu \mathrm{m}$. b (top) GE $\beta 1$ cells were synchronized by shake-off and

growth factor-induced p44/p42 MAPK phosphorylation was also considerably decreased, confirming the wellestablished link between integrin-mediated cytoskeletal organization and growth factor signaling [41-43]. Consequently, we observed a decline in cyclin D levels, in line with a number of reports showing that optimal cyclin D expression is jointly regulated by growth factors and integrin-mediated cell spreading and cytoskeletal organization [5, 12-15, 26-28]. However, the residual cyclin D levels were apparently sufficient to support G1-phase progression into S-phase, since expression of cyclin A was not treated with $\mathrm{CCD}$ or $\mathrm{LB}$ at the indicated time-points after synchronization. After $20 \mathrm{~h}$, the drugs were washed away and the cells were released in fresh medium. They were fixed $1 \mathrm{~h}$ later, and nuclei (blue), F-actin (red), and $\mathrm{P}(\mathrm{Y} 118)$ paxillin (green) were visualized with confocal microscopy. Bar $10 \mu \mathrm{m}$. Bottom GE $\beta 1$ cells were treated as in $\mathbf{b}$, fixed, and stained with DAPI. The percentage of mono- and bi-nucleated cells was determined from $\sim 300$ cells per experiment. The graph represents the averages \pm SEM from three independent experiments

prevented, and virtually all cells committed to DNA synthesis. It thus seems that for cells that enter G1-phase from mitosis, G1-phase progression does not depend on cytoskeletal tension. In fact, the vast majority of the cells completed the entire cycle in the absence of detectable actin filaments, giving rise to a population of giant binucleated cells due to absence of the actin contractile ring that separates the daughter cells during cytokinesis.

The results presented here complement our previous study, and suggest that cycling cells do not require an intact cytoskeleton or cell spreading, as long as expression of 
cyclin D is maintained. Furthermore, we now show that nuclear translocation of cyclin D during G1-phase of continuously cycling cells occurs independently of cell spreading/cytoskeletal organization. Thus, cyclin D expression (but not its nuclear translocation) depends on cell spreading and the cytoskeleton, which is in line with observations in cells that were growth factor-stimulated to re-enter G1-phase from G0 [44, 45]. Nuclear translocation of cyclin D is a key event in G1-phase that is required for phosphorylation of the retinoblastoma protein and passage of the restriction point [37]. However, export of cyclin D out of the nucleus and its subsequent cytoplasmic degradation are important for normal passage through S-phase $[46,47]$. It is thus paramount that nuclear trafficking of cyclin D is tightly regulated. Indeed, whereas overexpression of cyclin D is observed in many tumor cells, it is by itself not sufficient for oncogenic transformation, and accumulating evidence suggests that transformation is driven by nuclear retention of cyclin D [38]. Strategies that target the nuclear trafficking of D-type cyclins rather than merely their expression may therefore prove to be effective in the treatment of cancer. Because the expression of cyclin D is tightly linked to MAPK activity, and sustained MAPK activity throughout G1-phase until the restriction point is important for integrin-regulated cell cycle progression, an interesting question that arises from our data is whether the observed cell cycle progression in cells with disorganized cytoskeletons has become independent of MAPK. To delineate the cross-talk between MAPK, the cytoskeleton, and cell spreading in cycling cells, we inhibited the MAPK pathway using the inhibitor UO126. UO126 robustly inhibited progression to S-phase, but cell morphology and cytoskeletal organization, as well as FA assembly and integrin-stimulated autophosphorylation of FAK were not affected. Thus, although cell spreading and the cytoskeleton potentiate MAPK activation, the MAPK pathway seems not reciprocally involved in integrin signaling and integrinmediated cell spreading and cytoskeletal organization. Intriguingly, cell cycle progression in cytoskeleton-disrupted cells was also inhibited by UO126. These data thus identify the MAPK pathway as the mechanism that drives proliferation in the absence of cell spreading and cytoskeletal tension, and suggest that cell cycle progression can be uncoupled from tensional and morphological requirements by MAPK activation. It has been suggested that the tension-requirement for cell cycle progression differs between transformed and non-transformed cells, based on the observation that re-entry into G1-phase from quiescence is prevented by cytoskeletal disruption in non-transformed primary capillary endothelial cells and NIH3T3 fibroblasts overexpressing integrin $\alpha 5 \beta 1$ [5]. Indeed, transformation induces cell rounding and a loss of actin stress fibers, and a number of early reports have shown that actin-destabilizing agents do not affect proliferation in cycling transformed cells $[48-50]$. We therefore aimed to investigate whether integrin $\alpha 5 \beta 1$-supported cell cycle progression depends on cytoskeletal organization and cell spreading in cycling nontransformed cells. First, we generated NIH3T3 cells that stably overexpress $\alpha 5 \beta 1$, however shake-off experiments with this cell line did not yield sufficient numbers of mitotic cells (data not shown). We then chose GE $\beta 1$ cells as a model system, because they (1) predominantly express integrin $\alpha 5 \beta 1$ whereas the expression of other integrins is negligible, (2) display a well-spread, fibroblast-like shape with extensive actin stress fibers and FAs, (3) do not grow without growth factors or in soft agar, and (4) are importantly not tumorigenic in mice unless transformed with oncogenic Ras [40]. We thus consider GE $\beta 1$ cells to be a non-transformed cell line, at least with respect to growthcontrol mechanisms and cell cycle requirements. Intriguingly, cell cycle progression in cycling GE $\beta 1$ cells was not impaired by disruption of cytoskeletal integrity, cell spreading, and FA assembly in G1-phase, similar to what we have observed in $\mathrm{CHO}$ and $\mathrm{N} 2 \mathrm{~A}$ cells. We therefore conclude that cycling mammalian cells, transformed and non-transformed alike, can proliferate in the absence of cytoskeletal tension or cell spreading, provided that there is MAPK signaling to sustain threshold levels of cyclin D. Nevertheless, it is likely that cell cycle regulation in different cell types involves different regulatory mechanisms. For example, regulation of cell proliferation by cell shape and cytoskeletal tension has been well documented for fibroblasts and endothelial cells, which adopt a more "tensile" morphology than epithelial cells. Indeed, E-cadherin signals rather than cell-matrix interactions can drive cyclin D expression in epithelial cells [51]. Furthermore, whereas stress fibers are not commonly observed in cells in vivo, specialized cell types as wound fibroblasts and myofibroblasts develop them under conditions of great mechanical stress which require both proliferation and contraction, such as wound healing [52]. Probably, these cell types retain the tensional requirement for cell cycle entry from quiescence in vitro.

Acknowledgments We are grateful to Miriam van der Vaart and Jose Bijvelt for technical assistance.

Open Access This article is distributed under the terms of the Creative Commons Attribution License which permits any use, distribution, and reproduction in any medium, provided the original author(s) and the source are credited.

\section{References}

1. Howe A, Aplin AE, Alahari SK, Juliano RL (1998) Integrin signaling and cell growth control. Curr Opin Cell Biol $10: 220-231$ 
2. Hulleman E, Boonstra J (2001) Regulation of G1-phase progression by growth factors and the extracellular matrix. Cell Mol Life Sci 58:80-93

3. Margadant C, Monsuur HN, Norman JC, Sonnenberg A (2011) Mechanisms of integrin activation and trafficking. Curr Opin Cell Biol 23:607-614

4. Margadant C, Charafeddine RA, Sonnenberg A (2010) Unique and redundant functions of integrins in the epidermis. FASEB J 24:4133-4152

5. Assoian RK, Klein EA (2008) Growth control by intracellular tension and extracellular stiffness. Trends Cell Biol 18:347-352

6. Mammoto A, Ingber DE (2009) Cytoskeletal control of growth and cell fate switching. Curr Opin Cell Biol 21:864-870

7. Ohta T, Takasuka T, Ishibashi S, Ide T (1985) Cytochalasin D inhibits the progression from the G0 to S-phase at the mid-prereplicative stage in Gc-7 cells stimulated with serum. Cell Struct Funct 10:37-46

8. Takasuka T, Ishibashi S, Ide T (1987) Expression of cell cycledependent genes in serum stimulated cells whose entry into S-phase is blocked by cytochalasin D. Biochim Biophys Acta 909:161-164

9. Tsakiridis T, Bergman A, Somwar R, Taha C, Aktories K, Cruz TF, Klip A, Downey GP (1998) Actin filaments facilitate insulin activation of the src and collagen homologous/mitogen-activated protein kinase pathway leading to DNA synthesis and c-fos expression. J Biol Chem 273:28322-28331

10. Reshetnikova G, Barkan R, Popov B, Nikolsky N, Chang LS (2000) Disruption of the actin cytoskeleton leads to inhibition of mitogen-induced cyclin E expression, cdk2 phosphorylation and nuclear accumulation of the retinoblastoma protein-related p107 protein. Exp Cell Res 259:35-53

11. Lohez OD, Reynaud C, Borel F, Andreassen PR, Margolis RL (2003) Arrest of mammalian fibroblasts in G1 in response to actin inhibition is dependent on retinoblastoma pocket proteins but not on p53. J Cell Biol 161:67-77

12. Bottazzi MA, Buzzai M, Zhu X, Desdouets C, Brechot C, Assoian RK (2001) Distinct effects of mitogens and the actin cytoskeleton on CREB and pocket protein phosphorylation control the extent and timing of cyclin A promoter activity. Mol Cell Biol 21:7607-7616

13. Bohmer RM, Scharf E, Assoian RK (1996) Cytoskeletal integrity is required throughout the mitogen stimulation phase of the cell cycle and mediates the anchorage-dependent expression of cyclin D1. Mol Biol Cell 7:101-111

14. Huang S, Chen CS, Ingber DE (1998) Control of cyclin D1, p27 (Kip1) and cell cycle progression in human capillary endothelial cells by cell shape and cytoskeletal tension. Mol Biol Cell 9:3179-3193

15. Zhu X, Ohtsubo M, Bohmer RM, Roberts JM, Assoian RK (1996) Adhesion-dependent cell cycle progression linked to the expression of cyclin D1, activation of cyclin E-cdk2 and phosphorylation of the retinoblastoma protein. J Cell Biol 2:391-403

16. Mammoto A, Huang S, Moore K, Oh P, Ingber DE (2004) Role of RhoA, mDia and ROCK in cell shape-dependent control of the Skp2-p27kip1 pathway and the G1/S transition. J Biol Chem 18:26323-26330

17. Pennington SR, Foster BJ, Hauwley SR, Jenkins RE, Zolle O, White MRH, McNamee CJ, Sheterline P, Simpson AWM (2007) Cell shape-dependent control of $\mathrm{Ca} 2+$ influx and cell cycle progression in Swiss 3T3 fibroblasts. J Biol Chem 282:3211232120

18. Klein EA, Yung Y, Castagnino P, Kothapalli D, Assoian RK (2007) Cell adhesion, cellular tension, and cell cycle control. Methods Enzymol 426:155-175

19. Pages G, Lenormand P, L'Allemain G, Chambard JC, Meloche S, Pouyssegur J (1993) Mitogen-activated protein kinases p42 ${ }^{\text {MAPK }}$ and $\mathrm{p} 44^{\mathrm{MAPK}}$ are required for fibroblast proliferation. Proc Natl Acad Sci USA 90:8319-8323

20. Baldin V, Lukas J, Marcote MJ, Pagano M, Draetta G (1993) Cyclin D1 is a nuclear protein required for cell cycle progression in G1. Genes Dev 7:812-821

21. Weber JD, Raben DM, Phillips PJ, Baldassare JJ (1997) Sustained activation of extracellular-signal-regulated kinase 1 (ERK1) is required for the continued expression of cyclin D1 in G1-phase. Biochem J 326:61-68

22. Brondello JM, McKenzie FR, Sun H, Tonks NK, Pouyssegur J (1995) Constitutive MAP kinase phosphatase (MKP-1) expression blocks G1 specific gene transcription and S-phase entry in fibroblasts. Oncogene 10:1895-1904

23. Resnitzky D (1997) Ectopic expression of cyclin D1 but not cyclin $\mathrm{E}$ induces anchorage-independent cell cycle progression. Mol Cell Biol 17:5640-5647

24. Schulze A, Zerfass-Thome K, Berges J, Middendorp S, JansenDurr P, Henglein B (1996) Anchorage-dependent transcription of the cyclin A gene. Mol Cell Biol 16:4632-4638

25. Hansen LK, Albrecht JH (1999) Regulation of the hepatocyte cell cycle by type I collagen matrix: role of cyclin D1. J Cell Sci 112:2971-2981

26. Klein EA, Assoian RK (2008) Transcriptional regulation of the cyclin D1 gene at a glance. J Cell Sci 121:3853-3857

27. Danen EH, Sonneveld P, Sonnenberg A, Yamada KM (2000) Dual stimulation of the ras/mitogen-activated protein kinase pathway and RhoA by cell adhesion to fibronectin supports growth factor-stimulated cell cycle progression. J Cell Biol 151:1413-1422

28. Welsh CF, Roovers K, Villanueva J, Liu Y, Schwartz MA, Assoian RK (2001) Timing of cyclin D1 expression within G1phase is controlled by Rho. Nat Cell Biol 3:950-957

29. Margadant C, van Opstal A, Boonstra J (2007) Focal adhesion signaling and actin stress fibers are dispensable for progression through the ongoing cell cycle. J Cell Sci 120:66-76

30. Huang S, Ingber DE (2002) A discrete cell cycle checkpoint in late G1 that is cytoskeleton-dependent and MAP kinase (ERK)independent. Exp Cell Res 275:255-264

31. Ingber DE (1990) Fibronectin controls capillary endothelial cell growth by modulating cell shape. Proc Natl Acad Sci USA 87:3579-3583

32. Roovers K, Davey G, Zhu X, Bottazzi ME, Assoian RK (1999) Alpha5beta1 integrin controls cyclin D1 expression by sustaining mitogen-activated protein kinase activity in growth factor-treated cells. Mol Biol Cell 10:3197-3204

33. Hulleman E, Bijvelt JJM, Verkleij AJ, Verrips CT, Boonstra J (1999) Nuclear translocation of mitogen-activated protein kinase $\mathrm{p} 42^{\mathrm{MAPK}}$ during the ongoing cell cycle. J Cell Physiol 180:325-333

34. Hulleman E, Bijvelt JJM, Verkleij AJ, Verrips CT, Boonstra J (1999) Integrin signaling at the M/G1 transition induces expression of cyclin E. Exp Cell Res 253:422-431

35. Gimond C, van Der Flier A, van Delft S, Brakebusch C, Kuikman I, Collard JG, Fässler R, Sonnenberg A (1999) Induction of cell scattering by expression of betal integrins in beta1-deficient epithelial cells requires activation of members of the Rho family of GTPases and downregulation of cadherin and catenin function. J Cell Biol 147:1325-1340

36. Boonstra J, Mummery CL, Tertoolen LJG, van der Saag PT, de Laat SW (1981) Cation transport and growth regulation in neuroblastoma cells. Modulations of $\mathrm{K}^{+}$transport and electrical properties during the cell cycle. J Cell Physiol 107:75-83

37. Yamakita Y, Totsukawa G, Yamashiro S, Fry D, Zhang X, Hanks SK, Matsumura F (1999) Dissociation of FAK/p130 CAS/c-Src complex during mitosis: role of mitosis-specific serine phosphorylation of FAK. J Cell Biol 144:315-324 
38. Kim JK, Diehl JA (2009) Nuclear cyclin D1: an oncogenic driver in human cancer. J Cell Physiol 220:292-296

39. Danen EH, Sonneveld P, Brakebusch C, Fassler R, Sonnenberg A (2002) The fibronectin-binding integrins alpha5beta1 and alphavbeta3 differentially modulate RhoA-GTP loading, organization of cell matrix adhesions, and fibronectin fibrillogenesis. J Cell Biol 159:1071-1086

40. Huveneers S, van den Bout I, Sonneveld P, Sancho A, Sonnenberg A, Danen EH (2007) Integrin alphavbeta3 controls activity and oncogenic potential of primed c-Src. Cancer Res 67:2693-2700

41. Aplin AE, Juliano RL (1999) Integrin and cytoskeletal regulation of growth factor signaling to the MAP kinase pathway. J Cell Sci 112:695-706

42. Howe AK, Aplin AE, Juliano RL (2002) Anchorage-dependent ERK signaling-mechanisms and consequences. Curr Opin Genet Dev 12:30-35

43. Short SM, Talbott GA, Juliano RL (1998) Integrin-mediated signaling events in human endothelial cells. Mol Biol Cell 9:1969-1980

44. Aplin AE, Stewart SA, Assoian RK, Juliano RL (2001) Integrinmediated adhesion regulates ERK nuclear translocation and phosphorylation of Elk-1. J Cell Biol 153:273-282

45. Aplin AE, Juliano RL (2001) Regulation of nucleocytoplasmic trafficking by cell adhesion receptors and the cytoskeleton. J Cell Biol 55:187-191
46. Alt JR, Cleveland JL, Hannink M, Diehl JA (2000) Phosphorylation-dependent regulation of cyclin D1 nuclear export and cyclin D1-dependent cellular transformation. Genes Dev 14:3102-3114

47. Diehl JA, Cheng M, Roussel MF, Sherr CJ (1998) Glycogen synthase kinase-3beta regulates cyclin D1 proteolysis and subcellular localization. Genes Dev 12:3499-3511

48. Kurimura T, Hirano A (1980) DNA synthesis and multinucleation of mouse cells infected with SV40 in the presence of cytochalasin B. J Gen Virol 46:237-242

49. Maness PF, Walsh RC Jr (1982) Dihydrocytochalasin B disorganizes actin cytoarchitecture and inhibits initiation of DNA synthesis in 3T3 cells. Cell 30:253-262

50. Wittelsberger SC, Kleene K, Penman S (1981) Progressive loss of shape-responsive metabolic controls in cells with increasingly transformed phenotype. Cell 24:859-866

51. Fournier AK, Campbell LE, Castagnino P, Liu WF, Chung BM, Weaver VM, Chen CS, Assoian RK (2008) Rac-dependent cyclin D1 gene expression regulated by cadherin- and integrin-mediated adhesion. J Cell Sci 121:226-233

52. Pellegrin S, Mellor H (2007) Actin stress fibres. J Cell Sci 120:3491-3499 